\title{
"Aramıdaki Ortak Kelime:" Müslüman-Hıristiyan İlişkilerinde Güncel Bir Söz
}

Betül AVCI ${ }^{1}$

\section{Özet}

Farklı ülkelerden toplam yüz otuz sekiz Müslümanın imzasıyla 13 Ekim 2007 tarihinde açık mektup olarak yayımlanan "Aramızdaki Ortak Kelime" (AOK) ve bu metin çerçevesinde gelişen faaliyetler Müslüman-Hıristiyan ilişkilerindeki en güncel ve ses getiren diyalog girişimlerinden biri olmuştur. Bu mektubun başlangıcını "Amman Mesajı," “Amman Mesajı'nın Üç Noktası" ile "Papa XVI. Benedikt Cenapları'na Açık Mektup" oluşturmaktadır. Müslümanlarla Hıristiyanlar arasındaki barışın inşa ve ihyası amacıyla her iki din arasındaki teolojik farklılıkları inkâr etmeyen — ama askıya alan - AOK, polemik yerine daha büyük bir iyiliği gerçekleştirmek amaciyla ortak noktalar üzerine vurgu yapmayı tercih eder. Bunun için de her iki dinde ortak noktalar olarak gördüğü Tanrı'nın birliği, Tanrı ve kardeş/komşu sevgisi ile ilgili her iki dinin kutsal metinlerinden belirli bölümleri yan yana okumaya koyulur. Sonuç olarak, AOK metin olarak içerisinde zayıflıklar ve problemler barındırsa da onu sadece metin olarak değil, bağlamı ve etkisi itibarıyla değerlendirmek, "medeniyetler çatışması" tezine bir cevap olarak Müslümanların Hıristiyan komşularıyla bir ittifak kurma gayreti ve Hıristiyan dünyaya uzatılmış hem teolojik hem de siyasi bir el olarak görmek gerekir. Bu veçheden baktığımızda, AOK çerçevesinde farklı düşünce ve mezheplerden pek çok Müslüman uzun zamandır ilk kez birleşmiş ve yüzyıllardır erteledikleri inisiyatif sahibi bir konumda Hıristiyan dünyaya çağrıda bulunmuşlardır. Ayrıca AOK'ta Gelenekselci okulun "evrensel hikmet” ve sekülerleşmeye karşı savunduğu maneviyat vurgusu dikkat çeker.

Anahtar Kelimeler: Dinlerarası diyalog, "Aramızdaki Ortak Kelime," "Amman Mesajı," “Amman Mesajı'nın Üç Noktası," "Papa XVI. Benedikt Cenapları'na Açık Mektup.”

\section{"A Common Word Between Us and You,": A Contemporary Word on Muslim-Christian Relations}

\begin{abstract}
"A Common Word Between Us and You," dated 13 October 2007, is an open letter with one hundred and thirty-eight Muslim signatories. Since then both the letter and the events related to it have been among the most significant contemporary interreligious initiatives between Muslims and Christians. The genesis of "A Common Word" (ACW) dates back to "The Amman Message," "The Three Points of the Amman Message" and "Open Letter to His Holiness Pope Benedict XVI." ACW calls for peace between Muslims and Christians. For such an end, while not ignoring theological differences between the two traditions, it suspends them. ACW shies away from polemics and focuses on a common ground for a greater good. Hence, ACW sets out to quote sections from the Qur'an and the Bible that are both related to the unity of God, love of God and the love of neighbor. Consequently, the ACW text is not free from problems and it contains certain weaknesses. However, ACW should be assessed in respect to its context and impact rather than being considered solely as a text. Therefore, $\mathrm{ACW}$ is an attempt from Muslims that seeks to establish a common ground between themselves and their Christian neighbors. It is both a theological and political hand stretched to the Christian world as an answer to the "clash of civilizations" thesis. Thus, ACW brings together Muslims from various schools of thought and initiates dialogue with the Christian world for the first time in ages. Moreover, ACW's emphasis upon a "common wisdom" and spirituality against secularization, also stressed by the Traditionalist school, is significant.
\end{abstract}

Keywords: Interreligious dialogue, "A Common Word Between Us and You," "The Amman Message," "The Three Points of the Amman Message," "Open Letter to His Holiness Pope Benedict XVI."

\footnotetext{
${ }^{1}$ Yrd. Doç. Dr., Yalova Üniversitesi, İslami İlimler Fakültesi, Dinler Tarihi Bölümü.

E-posta: betulavci27@gmail.com.
} 


\title{
Giriș
}

Güncel Müslüman-Hıristiyan diyalog girişimlerinden biri sayılan "Aramızdaki Ortak Kelime" metni ve onun ekseninde ortaya çıkan faaliyetleri inceleyeceğim bu yazıda öncelikle bu girişimin bağlamı, arka planı, amacı, içeriği ve bulduğu yankı hakkında bilgi vereceğim. Ardından bu teşebbüsün günümüz Müslüman-Hıristiyan ilişkilerinde oynadığı rolü değerlendireceğim. Bu amaçla “Aramızdaki Ortak Kelime” çerçevesinde Dublin'de 6-7 Aralık 2013’te düzenlenen bir konferansa gözlemci olarak katıldığımı belirtmek isterim.

Türk Dil Kurumu'na göre "karşılıklı konuşma" anlamına gelen "diyalog" tabiri günümüz Türkiyesi'nde "dinlerarası diyalog" ile özdeş kullanılır olmuş, buna da büyük ölçüde olumsuz anlamlar yüklenmiştir. Aslında basitçe "farklı dinler ve inançlara mensup kişilerin iletişimi" olarak karşılayabileceğimiz "dinlerarası diyalog" tabiri günümüz Türkiyesi'nde "dinin ve vatanın elden gittiği bir mecra" olarak algılanmaktadır. Bu olumsuz yaklaşımın en önemli sebebi günümüz Türkiyesi'nde dinlerarası diyalog konusundaki algıyı yönlendiren ve son zamanlarda diyalog faaliyetleriyle Kuzey Amerika'da ve Avrupa'da adından sıkça söz ettiren Fethullah Gülen'e bağlı kurum ve kişiler olmuştur. Zira Gülen hareketi Türkiye kaynaklı olup dinlerarası diyalog alanında hem Türkiye içinde hem de beynelmilel düzeyde en fazla faaliyet gösteren gruptur. Bu konudaki diğer başlıca yaklaşım ise Gülen hareketinin sözde diyalog faaliyetleri ve bu konudaki fikirlerine gösterilen tepkilerdir. Elinizdeki bu yazıya iki öncülle başlamak istiyorum: Birincisi, dünya Türkiye'den büyüktür; diğeri, dinlerarası diyalog Gülenci hareketin bu isim altında gerçekleştirdikleri faaliyetlerden daha farklı, çeşitli, derin ve kapsamlıdır. Hülasa, bu yazıda beynelmilel düzeyde Müslüman-Hıristiyan ilişkileri ve bunlardan biri olan "Aramızdaki Ortak Kelime" girişimini Türkiye gündemindeki kısır tartışmalara girmeden değerlendirme niyetindeyim.

Öncelikle şunu belirtmekte fayda var: her bir diyalog girişimcisi ve katılımcısının böyle bir faaliyette yer almasında kendince bir amacı vardır. Bu sebeple de diyalog içerisindeki kurum, grup ya da bireylerin diyalogdan ne anladığını bilmek gerekir. Lübnanlı Sünni, sade bir Müslümanın diyalog anlayışı ile Alman Katolik bir akademisyeninki farklı olacaktır. Zira her ikisinin diyalog hakkındaki görüşünü kendine miras kalan tarihi bağlam, içinde bulunduğu coğrafya, karş1 karşıya olduğu sorunlar ve ihtiyaçlar belirleyecektir. Bu noktada Emre Öktem'in dinlerarası diyalogla ilgili tespitlerine kulak vermekte fayda var:

\begin{abstract}
Barışa hizmet için karşılıklı en iyi anlaşma arayışı ortak ideal olarak öngörülüyor, fakat cemaatlerin farklı beklentileri de var: Türk ilâhiyatçılar Hıristiyanlık konusunda bilgilenmeye çalışıyorlar, halbuki pek çoğu üstün derecede İslâm uzmanı olan Katolik ilâhiyatçılar "Türk” İslâm'ını tanımak arzusundalar. Doğu kiliseleri için diyalog, basit bir fikrî çabanın ötesinde, tarihî sebeplerden ötürü tanınmamış olan kimliklerini kabul ettirmenin ve yakın komşuları Müslümanlarla ilişkilerini düzeltmenin bir aracı olabilir. Fethullah Gülen'in Müslüman hareketi açısından dinler arası diyalog, dünya çapında yürüttükleri faaliyetlerin olmazsa olmaz bir şartıdır. Diğer Müslüman Türk hareket ve grupları açısındansa, dinler arası diyalog 24 Temmuz 1923 Lozan Anlaşması'nın III. Paragrafı gereğince, Türkiye'deki gayrimüslim azınlıkların faydalandıkları hukukî statüye benzer bir duruma fiilen erişmenin yolları arasında yer alabilir (Öktem, 2002: 137-138).
\end{abstract}

Dinlerarası diyalog Türkiye ve Ortadoğu'da pek çok sebepten olumsuz bir algıya sahiptir. Bunun en önemli nedenlerinden biri Müslüman Ortadoğulunun 
kendini açıkça ve gizlice sömüren Hıristiyan Batı dünyasına ve Siyonist Yahudilere olan güvensizliğidir. Zira Müslüman toplumlar son birkaç yüzyıldaki tecrübelerine dayanarak Batılı Hiristiyanları "misyoner" ve/veya "hegemonyac1," Yahudileri ise "işgalci” olarak görmektedir. Örneğin Kudüs'ün yerlisi ve Müslüman bir akademisyen olan Mustafa Ebu Suvey'e göre, Kudüs'te diyalog girişimleri ekseriyetle Yahudiler ve Hıristiyanlar arasındadır. Çünkü buradaki Müslümanlar siyasi ve dini sebeplerle diyalog faaliyetlerine kuşkuyla bakmakta ve bunlara katılmamaktadır (kişisel görüşme, 6 Aralık 2013).

Diyaloğa karşı olumsuz telakkinin bir diğer sebebi ise günümüzde büyük ölçüde varoluş mücadelesi veren Ortadoğu ve Müslüman dünyanın bu mevzuyu pek tabii bir lüks olarak görmesidir. Zira pek çok çeşidinden bahsedebileceğimiz dinlerarası diyaloğun hâlihazırdaki sorunlara birer çözüm sunacağı şüpheyle karşılanmaktadır. Ayrıca toplumun köklerinden gelmeyen herhangi bir diyalog girişiminin suni bir dayatmacılık olduğu, en iyi ihtimalle fuzuli bir faaliyet olduğu görüşü mevcuttur. Sonuç olarak, Ortadoğu ve günümüz Türkiyesi'nde diyalog dendiğinde akla gelebilecek en olumlu şey Müslüman ve gayrimüslimlerin bir araya gelerek pratik hiçbir amaca hizmet etmeyen afaki konuşmaları olacaktır. Ayrıca, günümüzde dinlerarası diyalog konusunda Batılı Hıristiyanların herkesten önde olduğu, diyalog dilinin ise çoğunlukla İngilizce olduğu bir gerçektir. Müslümanların diyalog alanında üstünlük ve öncelik sahibi olmamalarının başlıca iki sebebi vardır: Bunlardan ilki, Batılı Hıristiyanların ekonomik ve politik açılardan Müslüman toplumlardan daha gelişmiş olması; diğeri ise, Müslüman toplumlarda dinlerarası değil kendi iç, yani mezhepler arası problemlerinin öncelikli olmasıdır.

Farklı din mensupları arasındaki diyaloğun günümüz dünyasında hâlihazırda var olan bir durum olduğu görülür. Farklı görüş ve okullardan olan Müslüman şahıslar, gruplar ve kurumlar gayrimüslimlerle diyaloğu kendi anlayışları doğrultusunda zaten yürütmekteler. Lakin ne yazık ki, günümüz Türkiyesi'nde bırakın dinlerarası diyaloğa yapıcı ya da yapı-bozucu eleştiriler getirmeyi, bu mevzudan söz edildiğinde mecaz-1 mürseli bile aşamayıp "dinlerarası diyalog olmaz, din mensupları arasında diyalog olur" eleştirisinde takılıp kalıyoruz. Umarım bu yazı okuyucuya dinlerarası diyaloğa güncel bir yaklaşım olan "Aramızdaki Ortak Kelime" girişimini irdelemek suretiyle - Türkiye'deki kısır gündeme sıkışıp kalmadan — konu üzerinde düşünmesi için bir firsat verir.

\section{1. "Aramızdaki Ortak Kelime"nin Arka Planı ve Bağlamı}

Müslümanlarla Hıristiyanlar arasındaki ilişkilerin geçmişini İslamiyet'in en erken dönemlerinden başlayarak günümüze kadar getirmek mümkündür. ${ }^{2}$ "Aramızdaki Ortak Kelime" (bundan sonra kısaca AOK) metni tür olarak bir mektup niteliği taşır zira, tüm dünyadaki Hıristiyan liderlere hitap etmektedir. Bu tarz mektup örneklerini İslamiyet'in ilk dönemlerinden itibaren, Hz. Muhammed'in Bizans İmparatoru Heraklius'a gönderdiği mektup örneğinde olduğu gibi, görmek mümkündür. Rana Kabbani’nin 1989 yılında kaleme aldığı "Hıristiyan Dünyaya

${ }^{2}$ Müslüman Hıristiyan ilişkilerinin detaylı tarihçesi için bk. Gaudeul, J.M. (2000). Encounters and Clashes: Islam and Christianity in History, Vol. I, A Survey. Roma: Pontificio Istituto di Studi Arabi e d'Islamistica. 
Mektup" bu türün modern örneklerinden sayılabilir. Kabbani, Selman Rüşdi olayının akabinde kaleme aldığı mektubunda Hıristiyan dünyaya Müslümanların dini ve kültürel duruşunu anlatmaya çalışmaktadır. Aynı şekilde AOK metni farklı ülkelerden toplam yüz otuz sekiz Müslümanın imzasıyla 13 Ekim 2007 tarihinde açık mektup olarak yayımlanmıştır. Bu mektubun başlangıç noktasını "Amman Mesajı" ile Papa XVI. Benedikt'in Regensburg Üniversitesi'ndeki konuşması ve bu konuşma akabinde bir grup önde gelen Müslümanın Papa'ya cevap olarak yazdıkları "Papa XVI. Benedikt Cenapları'na Açık Mektup" oluşturmaktadır.

“Amman Mesajı"nın ve “Amman Mesajı'nın Üç Noktası” olarak adlandırılan bildirinin gayesi İslam'ın gerçek mesajını dünyaya açıklamaktı. Amacı modern dünyaya hakiki İslam'ı anlatmak olan "Amman Mesajı" ilk olarak 9 Kasım 2004'de Amman'da Ürdün Kralı II. Abdullah'ın da hazır bulunduğu bir hutbede okundu. Ardından bu mesaja dini bir otorite kazandırmak amacıyla Kral II. Abdullah dünyanın dört bir köşesindeki farklı mezhep ve görüşten olan, önde gelen yirmi dört Müslüman âlimden şu üç sorunun cevabını istedi:

1. Müslüman kimdir?

2. Birini kâfir ilan etmek caiz midir?

3. Dini fetva verme yetkisi kime aittir?

Aralarında Ayetullah Sistani, Şeyh Karadavi ve Ezher şeyhinin de bulunduğu pek çok âlimin fetvasına binaen Kral II. Abdullah Temmuz 2005'de Krallık Ehl'ül-Beyt (Royal Aal al-Bayt) Enstitüsü tarafından gerçekleştirilen "Modern Toplumda Gerçek İslam ve Rolü" başlıklı uluslararası bir İslam konferansı düzenledi. Bu konferansın akabinde Amman'da buluşan ellinin üzerindeki ülkeden sayıları iki yüzü bulan Müslüman âlim ittifakla bir karar bildirisi yayımladı. "Amman Mesajı'nın Üç Noktası" olarak anılagelen bu bildiriye göre şu kararlar üzerinde birleşildi:

1. Sünni (Hanefi, Maliki, Şafi, Hanbeli), Şii (Caferi, Zeydi) ile İbadi ve Zahiri'den oluşan sekiz fikhi mezhep, Eş'arilik, tasavvufi ve hakiki Selefi düşünce sahihtir; bu hükme binaen Müslümanların birbirlerini tekfir etmeleri yasaktır.

2. Yukarıda sözü edilen fikhi mezhepler, başlıca İslami ve imanla ilgili şartlarda hemfikirdir.

3. Fetva verme konusunda bu sayılan mezhep ve görüşlerin dışındakiler yetkili değildir. ${ }^{3}$

Resmi sayfasında yer alan bilgiye göre bu bildiriyi Temmuz 2006 tarihi itibarıyla imzalayanların sayısı beş yüz elli ikidir. Bildiriyi Türkiye'den dönemin Diyanet İşleri başkanı Ali Bardakoğlu ile İstanbul müftüsü Mustafa Çağrıcı'nın da aralarında bulunduğu pek çok isim imzalamıştır. Sonuç olarak, kendi tabiriyle, bu bildiri ile İslam ümmeti bin yılı aşkın süredir ilk kez resmi bir görüş birliğine varmış, kendi içindeki farklı mezhep ve grupları tanımak suretiyle ümmet olma bilincini idrak etmiştir. Din içi diyaloğun günümüzdeki en önemli adımlarından biri

\footnotetext{
3 “Amman Mesajı” ve “Amman Mesajı'nın Üç Noktası” metinlerine şu adresten ulaşılabilir: http://ammanmessage.com/ (15 Ekim 2016).
} 
sayılabilecek bu girişim, AOK'taki dinlerarası diyaloğa giden yolda önemli bir adım olmuştur.

AOK'a zemin hazırlayan bir diğer metin olan "Papa XVI. Benedikt Cenapları'na Açık Mektup" ise dünya çapında önde gelen otuz sekiz Müslümanın imzasıyla 13 Ekim 2006'da yayımlanmıştır. Papa XVI. Benedikt 12 Eylül 2006 tarihinde daha önce öğretim üyeliği de yaptığı Almanya'daki Regensburg Üniversitesi’nde, "İman, Akıl ve Üniversite: Hatıralar, Değerlendirmeler" başlıklı bir sunum yaptı. Konuşmasında 14. yy. Papa'nın Bizans İmparatoru Manuel II. Palaiologos'tan alıntıladığı şu ifade dünya genelinde büyük tepkiye yol açtı: "Bana Muhammed'in getirdiği yeniliği göster. Göreceksin ki, sadece kötü ve insanlık dişı şeyler, vaz ettiği inancın kılıç yoluyla yayılmasını emretmesi gibi." Papa'nın Manuel II. Palaiologos'tan yaptı̆̆ 1 bu alıntının yanı sıra Kur'an-1 Kerim'de geçen "Dinde zorlama yoktur" (Bakara, 256) ayeti hakkındaki yorumu Müslüman dünyada büyük tepkilere yol açtı. Papa bazı "uzmanlara" dayanarak bu ayetin Hz. Muhammed'in nübüvvetinin ilk yıllarında, yani onun "güçsüz ve tehdit altında" bulunduğu dönemde nazil olduğunu iddia eder. Devamında, Kur'an'daki cihatla ilgili ayetlerin Hz. Peygamber'in nübüvvetinin geç dönemine ait olduğunu belirtir. Bu gelişmenin akabinde dünyanın pek çok yerinde Müslümanlar Papa'nın mezkûr konuşmasını protesto etmek için sokaklara dökülmüş, Müslümanlarla Hıristiyanlar arasında gerginlikler yaşanmıştır. Papa bu tepkilere karşı herhangi bir özür beyanında bulunmamış - fakat ayrı bir not olarak - Vatikan resmî sitesindeki konuşma metnine dipnot olarak şu yorumu eklemiştir:

\begin{abstract}
Ne yazık ki, bu alıntı Müslümanlar tarafından şahsi fikrimmiş gibi algılandı ve anlaşılabilir bir öfke yarattı. Umarım metin okunduğu anda görülecektir ki, bu cümle benim büyük bir dinin kutsal kitabı olarak saygı duyduğum Kur'an hakkındaki şahsi düşüncemi ifade etmez. İmparator II. Manuel'in sözlerini alıntılamaktaki tek amacım iman ve akıl arasındaki asli ilgiyi açıklamaktı. Bu noktada II. Manuel ile aynı kanaatteyim, fakat polemiğini onaylamıyorum (İman, Ak1l ve Üniversite, dip. 3).
\end{abstract}

Dönemin T.C. Diyanet İşleri Başkanı Ali Bardakoğlu Papa XVI. Benedikt'in sözlerine ilk tepki veren dini liderlerden biri olmuş, verdiği demeçte Papa'nın sarf ettiği sözleri "kışkırtıcı, düşmanca, ön yargılı ve taraflı bir bakış" olarak değerlendirmiştir (Bardakoğlu, 2006). Bir diğer önemli tepki ise AOK'un ortaya çıkmasında önemli rol oynayan isimlerden Arif Ali Nayid'den gelmiştir. Nayid Papa'nın konuşması üzerine yaptığı yorumda ne Endonezya'ya ne de Malezya'ya hiçbir Müslüman ordu girmediği halde bu iki ülkenin diğer bütün Arap ülkelerininkinden daha fazla Müslüman nüfusa sahip olmalarına dikkat çekmiştir. Ardından, geçmişte Müslümanların egemenliklerinde olan ülkelerde hala Hıristiyan azınlıklar bulunurken Katolik Ferdinand ve İzabel'in İspanya'y1 ele geçirmelerinden sonra Müslüman ve Yahudilerin sayısının sayılamayacak kadar azaldığını belirtmiştir (Nayed, 2006).

Papa XVI. Benedikt'in Regensburg konuşmasının akabinde sayıları otuz sekizi bulan Müslüman dünyanın önde gelen şahısları ortaklaşa imzaladıkları bir mektupla Papa'ya seslenmişlerdir. 13 Ekim 2006'da yayımlanan "Papa XVI. Benedikt Cenapları'na Açık Mektup"un daha ilk paragrafında Papa'nın Regensburg konuşmasına atfen şu ifadelere yer verilir: "İnsan hayatındaki pozitivizmin ve materyalizmin hâkimiyetine karşı giriştiğiniz mücadeleyi alkışlamakla birlikte, 
İslam'ın aklın doğru şekilde kullanılmasına zıt olduğu şeklindeki ifadenizdeki bazı hataları, ayrıca iddianıza destek olarak ortaya koyduğunuz ifadelerdeki birtakım yanlışlıkları göstermek zorundayız."

Papa'nın mezkûr sözleri ile ifade bulan yanlış anlayışı düzeltmek için Allah'ın aşkınlığı, aklın kullanılması, cihat, zorla din değiştirme gibi konular hakkında İslam'ın bakışını özetleyen bu mektup, cevap niteliğinde ve savunmacı bir üsluptadır. Sonuç olarak, Papa ne Regensburg'ta sarf ettiği sözler sebebiyle özür dilemiş ne de Joseph Lumbard'ın belirttiğine göre, Müslümanlardan gelen bu mektuba cevaben Prens Gazi bin Muhammed'e nezaket ziyaretinden başka bir girişimde bulunmuştur (Lumbard, 2012: 16). Papa'ya hitaben kaleme alınan bu mektuptan tam bir yıl sonra yazılacak AOK mektubu ilkinden büyük ölçüde farklıdır. Zira inisiyatif sahibi bir üslupta Müslümanlar ve Hıristiyanlar arasında ortak bir noktada buluşmayı hedeflemekte, karşı tarafa elini uzatmaktadır. AOK sadece Katolik dünyanın lideri Papa'yı değil tüm Hıristiyan kiliseleri ve onların liderlerini muhatap almış, barış, birlik, adalet gibi kavramların sıkça yer aldığı pozitif bir dil kullanmıştır.

\section{2. "Aramızdaki Ortak Kelime" (AOK) $)^{4}$}

Papa XVI. Benedikt'e hitaben yazılan açık mektuptan tam bir yıl sonra, 13 Ekim 2007'de sayıları yüz otuz sekize ulaşan Müslüman âlim ve akademisyenden oluşan bir grup, pek çoğu ismen anılan Hıristiyan liderlerinin nezdinde, tüm Hıristiyan dünyaya hitaben açık bir mektup yayımlamıştır. "Aramızdaki Ortak Kelime" olarak bilinegelen bu mektup, Ürdün Prensi Gazi bin Muhammed tarafindan kaleme alınmış, Mısır'dan Şeyh Ali Cuma, Suriye'den Şeyh Sa'id Ramazan el-Buti, Bosna'dan Mustafa Ceriç, Seyyid Hüseyin Nasr ve Tim Winter'ın (Abdülhakim Murad) da aralarında bulunduğu âlimler topluluğu tarafından kontrol edilip onaylanmıştır. Ürdün Kralı II. Abdullah'ın ve Krallık Ehl'ül-Beyt (Royal Aal al-Bayt) Enstitüsü’nün bu girişimde katkısı büyüktür. Zira Kral II. Abdullah'ın ev sahipliğini yaptığı ve bu enstitü tarafından Eylül 2007'de düzenlenen 'Kur'an'da Sevgi" temalı konferansta AOK metninin son hali katılımcılara sunulmuş̧ur. Ayrıca bu kuruluş “Amman Mesajı”ndan başlayarak devam eden süreci, kendi misyonu ile birleştirmiştir. ${ }^{5}$

\footnotetext{
4 “Aramızdaki Ortak Kelime” ile ilgili bazı kaynaklar şunlardır: MABDA. (2012). A Common Word Between Us and You 5-Year Anniversary Edition. Amman: The Royal Aal Al-Bayt Institute for Islamic Thought (Bu kitap AOK'un resmi sayfasından ücretsiz indirilebilir); Demiri, L. vd. (Eds.). (2011). A Common Word: Texts and Reflections: A Resource for Parishes and Mosques. Cambridge: Muslim Academic Trust; Nnabugwu, J. (2011). Analyzing a Common Word Between Us Muslims and You Christians: A Critical Discourse Analysis (CDA). Bloomington: Xlibris Corp.; Volf, M. vd. (Eds.). (2010). A Common Word: Muslims and Christians on Loving God and Neighbor. Grand Rapids: Eerdmans; El-Ansary, W. vd. (Eds.). (2010). Muslim and Christian Understanding: Theory and Application of "A Common Word." New York: Palgrave Macmillan; Borelli, J. (Ed.). (2009?). A Common Word and the Future of Christian-Muslim Relations. Washington, DC.: Georgetown University; Colwell, P. (2008). Above Us and Between Us: An Introduction and Resource and Resource on the Letter "A Common Word Between Us and You” Signed by 138 Muslim Scholars. London: Churches Together in Britain and Ireland.

${ }^{5}$ Krallık Ehl'ül-Beyt Enstitüsü (Royal Aal al-Bayt Institute) amacı İslam'a ve tüm insanlığa hizmet olan Ürdün merkezli, uluslararası, bağımsız bir İslami sivil toplum kuruluşudur. Enstitü İslam hakkında varsayılan yanlış düşüncelerin düzeltilmesine, mezhepler arası ve dinlerarası diyalog
} 
AOK'u imzalayan isimlere göz attığımızda her birinin kendi ülkelerinde önemli sosyal, dini ve siyasi statüye sahip şahıslar oldukları görülür. Bu kişiler sadece dünyanın dört bir köşesindeki kitlelere hitap eden dini liderler, âlimler, entelektüeller, sivil toplum kuruluşu liderleri değil, aynı zamanda Sünni, Şii, Selefi ve tasavvuf ehli olarak İslam dünyası içerisindeki farklı gelenekleri temsil eden kişilerdir. Mektup, Ürdün Prensi Gazi bin Muhammed ve Arif Nayid'in ifadesiyle, "ümmetin âlimlerinin bağlayıcı görüş birliğini oluşturmaktadır" (Ghazi bin Muhammad ve Nayed, 2010: 173).

\title{
2. 1. "Aramıdaki Ortak Kelime"nin Amacı
}

Mektubun tam başlığında bulunan "bizimle sizin aranızdaki ortak bir kelime (a common word between us and you)" ifadesi Âl-i İmran Suresi'ndeki 64. ayete bir atıftır: "De ki: 'Ey kitap ehli! Bizimle sizin aranızdaki ortak bir kelimeye gelin: Yalnız Allah'a ibadet edelim. O’na hiçbir şeyi ortak koşmayalım. Allah'ı bırakıp da kimimiz kimimizi ilah edinmesin.' Eğer onlar yine yüz çevirirlerse, deyin ki: 'Şahit olun, biz Müslümanlarız." AOK'u kaleme alan Prens Gazi bin Muhammed bildirinin amacını şu şekilde özetler:

\begin{abstract}
Samimi olmak gerekirse... tek bir amacımız vardı: barıș. Tüm dünyada Hıristiyanlarla Müslümanlar arasında — devletler ve sözleşmeler vasıtasıyla değil de en önemlisi toplum ve halk düzeyinde — tam anlamıyla dünyadaki halk nezdinde en etkin liderleri, yani her iki dinin liderleri vasıtasıyla barış ve düzeni yaymayı denemeyi amaçlıyorduk. (Her iki taraftan da) artan yaygın karar birliği olmasından korktuğumuz dünya çapında (ve bu sebeple de tahripkâr ve belki de dünyanın sonu olacak) Müslüman-Hıristiyan cihadı/haçlı savaşının tamtam seslerini durdurmak istedik. Ancak, hakikaten farkındaydık ki, barıș çabaları bașka bir unsur daha gerektirir: bilgi. Bu sebeple, İslamiyet'e, özellikle de Batı'da, haksız yere sürekli atılan iftirayı düzeltmek ve dindirmek için dinimiz hakkında gerekli temel bilgiyi yaymayı amaçladık (Ghazi bin Muhammad, 2010: 9).
\end{abstract}

AOK Müslümanlarla Hıristiyanlar arasındaki barışın inşa ve ihyası amacı çerçevesinde - aralarındaki teolojik farklılıkları inkâr etmeden — ortak noktalar üzerinde buluşmayı tercih eder. Bu tercih ise AOK'un metodunu ortaya koyar: Polemik yapmak ya da teolojik farklıllklar üzerinde durmak yerine, daha büyük bir iyiliği gerçekleştirmek amacıyla ortak noktalar üzerine vurgu yapmak. Bizzat gözlemci olarak katıldığım 6-7 Aralık 2013'de Dublin'de düzenlenen AOK konferansında metnin hazırlanmasında rol alan önemli isimlerden biri olan Cambridge Üniversitesi'nden Tim Winter (Abdulhakim Murad) metnin ortaya çıkma süreciyle ilgili ilk elden bilgiler verdi. Winter'a göre AOK, dönemin Papası XVI. Benedikt'e karşı değil, George W. Bush ve zamanının teopolitik faaliyetlerine, Amerikan politikasının dini söylemine bir tepki olarak kaleme alınmıştır (Winter, 2013). Zira bu dönem 11 Eylül saldırılarının akabinde ABD'nin Ortadoğu'yu işgaline denk düşmektedir. ABD'nin bu tutumu ise Müslüman dünyanın endişesini artırmıştır. Bu noktada Tim Winter'ın da sözünü ettiği Bush'un 16 Eylül 2001'deki basın toplantısında sarf ettiği "bu haçlı savaşı, teröre karşı bu savaş bir süre devam

çalışmalarına önem vermektedir. Kurum hakkında detaylı bilgi için bk. http://www.aalalbayt.org/index.html (15 Ekim 2016). 
edecek" sözlerini hatırlamak gerekir. ${ }^{6}$ Zira Bush'un sarf ettiği "haçlı savaşı" tabiri o dönemde Müslüman dünyada ciddi bir gerilim yaratmıştı. Hatırlamak gerekir ki, bu dönem (özellikle Müslüman dünyada) Bush'un evanjelik dini emelleri doğrultusunda yeni dünya düzenini kurmak için yeni savaşlar başlatma planlarının konuşulup tartışıldığı bir ortamdı.

\section{2. "Aramıdaki Ortak Kelime" Metni}

AOK metni aralarında Papa XVI. Benedikt ve Ortodoks Patriği I. Bartholomeo'nun da bulunduğu tüm Hıristiyan liderlere hitapla başlar. Ardından Hıristiyanları Allah'ın birliği, Allah sevgisi ve kardeş/komşu ${ }^{7}$ sevgisi gibi üç ortak nokta etrafında birleşmeye çağıran metin, Müslümanın kim olduğunu ve İslamiyet' in temel şartını belirtir. Yani, "Allah'tan başka ilah yoktur ve Muhammed O'nun resulüdür" düsturunu kabul eden Müslüman, etmeyen ise Müslüman değildir. Metin akabinde Kur'an'dan ayetler ve hadisler nakleder. Bu ayet ve hadislerin ortak noktas Allah'ın yegâne ilah olması ve yalnızca O'na kulluk edilmesi gerektiğidir. Ardından, Kur'an'a atfen İslam felsefecilerinin yüzyıllar içerisinde sistemli hale getirdiği nefsin üç gücünden bahseder: akıl, irade ve his. İnsanın nefsinin tüm güçleriyle ve "manevi kalple" kendini Allah'a adaması üzerinde duran bu bölümdeki tasavvufi ve felsefi kavramlar ve yorum dikkatlerden kaçmaz. Sonuç olarak metne göre, "İslam'da Allah sevgisi sadece geçici ve kısmi bir his değil, Allah'a tam ve mutlak olarak adanmanın bir parçasıdır" (The 'A Common Word' Text, 2012: 61).

Metinde de geçen Hıristiyanlık'taki tek Tanrı anlayışı, Tanrı ve kardeş/komşu sevgisi Kitâb-ı Mukaddes'teki başlıca iki bölüme dayanır. Bunlardan ilkinde şöyle seslenilir: "Dinle, ey İsrail! Tanrımız Rab tek Rabdir. Tanrınız Rabbi bütün yüreğinizle, bütün canınızla, bütün gücünüzle seveceksiniz" (Tesniye 6:4-5). Diğerinde ise İsa Kutsal Yasa'daki en önemli buyruktan şu şekilde bahseder: "Tanrın olan Rabbi bütün yüreğinle, bütün canınla ve bütün aklınla sev. İşte ilk ve en önemli buyruk budur. İlkine benzeyen ikinci buyruk da şudur: Komşunu kendin gibi sev. Kutsal Yasa'nın tümü ve peygamberlerin sözleri bu iki buyruğa dayanır" (Matta 22: 37-40). Hz. Muhammed'in "ben ve benden önceki peygamberlerin söylediği en hayırlı şey şu sözdür: Allah'tan başka ilah yoktur, yalnız O vardır, O'nun benzeri yoktur, mülk ve övgü O’na aittir ve O'nun her şeye gücü yeter" (Tirmizî, Sünen, Da'avât, No. 139) hadisiyle Kitâb-1 Mukaddes'te ilk emir olarak geçen Tanrı'nın "tüm yürekle ve canla" sevilmesini anlam itibarıyla birbirine çok benzer bulan AOK metni Hz. Muhammed'in Kitâb-1 Mukaddes'in bu emrini "ilham vasitasılyla

\footnotetext{
${ }^{6}$ Bush'un Amerikan politikasında kullandığı din dili hakkında kapsamlı bir çalışma için bk. Lincoln, B. (2002, 2006). Holy Terrors: Thinking About Religion After September 11. Chicago \& London: University of Chicago Press.

${ }^{7}$ Elinizdeki yazı içerisinde orijinal AOK metninde geçen "neighbour" tabirini "kardeş/komşu” olarak karşılamayı tercih ettim. Zira metinde geçen "neighbour" iki referansa dayanır: 1) Matta İncili 22:39: "Komşunu (plēsion/ $\pi \lambda \eta \sigma i ́ o v)$ kendin gibi seveceksin." 2) Hadis-i şerif: "Sizden biriniz kendisi için istediğini kardeşi (أخ ) için istemedikçe iman etmiş sayılmazsınız" (Buharî, Sahih, İman, No. 13). AOK'un da metin içerisinde yer verdiği gibi bu hadis çoğunlukla "kardeşi”" kelimesi ile rivayet ediliyor olsa da bazı rivayetlerde "komşusu (جاره )" ş̧eklinde geçer (The “A Common Word' Text, 2012: 66).
} 
tekrarlıyor ve ona gönderme yapıyor" olabileceğini iddia eder (The "A Common Word' Text, 2012: 65).

AOK'un bir sonraki bölümünde ise kardeş/komşu sevgisinden bahseden Kur'an ayetleri, hadisler ve Kitâb-1 Mukaddes'ten kısımlar zikredilir. Sonuç olarak ise iki kutsal kitabın da Allah'ın birliğini bildirdiği, insanları Allah'tan başkasına tabi olmamaya, Allah'1 ve kardeşini/komşusunu sevip barış içinde yaşamaya çağırdığı belirtilmektedir. Sonlara doğru daha net anlaşılacağı üzere, burada kardeş/komşu sevgisinden başlıca kasıt "adalet" ve "inanç özgürlüğüdür" (The 'A Common Word' Text, 2012: 70). İki din arasındaki farklılıklara da vurgu yapan metin Hıristiyanları ortak noktalar etrafında bir araya gelmeye davet eder ve şu sözlerle sona erer: "Farklılıklarımızın aramızda nefret ve çekişme yaratmasına izin vermeyelim. Birbirimizle ancak doğruluk ve iyi işlerde yarışalım. Birbirimize karşı sayg1lı, dürüst, adaletli ve müşfik olalım. Gerçek barış, uyum ve karş11ıklı iyi niyet içerisinde yaşayalım” (The 'A Common Word' Text, 2012: 73).

AOK'un üslubuna baktığımızda sade, kolay anlaşılan ve özenli bir dil kullandığı görülür. Hıristiyanlara üstten bakmayan bir dille kaleme alınması çok yankı bulmasının başlıca sebeplerinden biridir. Örneğin metin içerisinde birkaç yerde "muhtemelen (perhaps)" tabirinin geçmesi Hıristiyan tarafa karşı açık olma, birlikte düşünmeye davet etme anlamına gelir. Ayrıca metinde geçen "en iyisini Allah bilir" ifadesi insan aklı ve bilgisinin sınırlılığını, Allah'ın önünde saygıyla eğilmeyi, O'na sormayı ve O'ndan yardım dilemeyi ifade eder.

\section{3. “Aramızdaki Ortak Kelime"nin Yankıları}

Bildirinin akabinde içlerinde Papa XVI. Benedikt, Rus Ortodox Patriği II. Alexi, Ermeni Ortodoks Katolikosu I. Aram, zamanın Canterbury Başepiskoposu Rowan Williams, diğer Ortodoks ve Doğu Ortodoks kiliselerinin patrikleri, Lutheran, Presbiteryen, Baptist, Metodist ve diğer pek çok kilise temsilcisi ile içlerinde Christian W. Troll, Daniel Madigan, Tom Michel, John Esposito, Karen Armstrong gibi öne çıkan din adamı ve akademisyenlerin olduğu pek çok isim cevap verdi. Joseph Lumbard'a göre, Vatikan başta AOK'a olumlu cevap vermeye pek yanaşır görünmemişse de "Yale Cevabı"nın etkisiyle hemen Müslüman-Katolik Forumu’nun kurulmasına öncülük eden girişimlere başlamıştır (Lumbard, 2012: 1617).

AOK'a gelen cevaplar arasında en çok ilgi görenlerden biri Yale Üniversitesi'ndeki birkaç akademisyen tarafından hazırlanıp imzaya açılan ve 18 Kasım 2007'de New York Times'da yayımlanan "Loving God and Neighbor Together: A Christian Response to A Common Word Between Us and You" adlı karşılık mesajı oldu. Bu mesaj ayrıca "Yale Cevabı" olarak da bilinir. "Yale Cevabı," AOK'u "tarihi" bir belge olarak adlandırır. Zira mektup dünyanın dört bir yanından pek çok Müslüman âlim ve din adamı tarafından imzalanmıştır. "Yale Cevabı" AOK'u Müslümanların Hıristiyanlara uzattığı el olarak görmekte, bu eli Hıristiyanlar olarak kabul ettiklerini belirtmekte ve karşılığında kendi ellerini uzatmaktadırlar: "Bu cevapta karşılık olarak kendi Hıristiyan elimizi uzatıyoruz ki, Tanrı'yı ve komşularımızı sevme peşinde koşarken diğer tüm insanlarla birlikte barış ve adalet içinde yaşayalım." 
"Yale Cevabı" diğer cevap ve yaklaşımların pek çoğundan farklıdır. Zira AOK'un içeriğinden ziyade pratik amacı ve sonucuyla ilgilenir. Çünkü bu mektubun Müslüman dünyada yüzyıllardır atılan en önemli diyalog adımı olduğunun farkındadır. Bu sebeple, cevabın tonundaki hüsnü kabul ve coşku dikkatlerden kaçmaz. Buna ilaveten, genel Hıristiyan yaklaşımlarından farklı olarak, kendi dindaşlarından eleştiri alma pahasına, Hz. Muhammed için "peygamber" tabirini kullanıp Müslümanlardan geçmişteki Haçlı savaşları ve hâlihazırdaki "teröre karşı savaş" adı altında yapılanlardan dolayı af diler:

\begin{abstract}
Müslümanlar ve Hıristiyanlar hep dostça el sıkışmamışlardır; aralarındaki ilişki bazen gergin, hatta tam bir husumet olarak değerlendirilebilir. İsa Mesih "Önce kendi gözündeki merteği çıkar, o zaman kardeşinin gözündeki çöpü çıkarmak için daha iyi görürsün" (Matta 7:5) dediği için geçmişte (örn., Haçlı Savaşları'nda) ve şu anda (örn., "teröre karşı şavaş"1n aşırılıklarında) pek çok Hıristiyanın Müslüman kardeşlerimize karşı günah işlediği için suçlu olduğunu teslim ederek başlamak istiyoruz. Mektubunuza cevaben "elinizi sıkma"dan önce, Rahman'ın ve tüm dünyadaki Müslümanların affını diliyoruz (Loving God and Neighbor Together).
\end{abstract}

"Yale Cevabı"nın başını çekenlerin önemli özellikleri arasında Müslümanlarla yakın ilişki kurmuş, ruhban, kapsayıcı Protestan teoloji ve pratiği benimsiyor olmaları gelir. Örneğin Afrikalı-Amerikalı ruhban bir Baptist olan Emilie M. Townes kendisini "1rk, cinsiyet, sınıf, etnik köken, ya da cinsel tercih ayrımı olmaksızın tüm insanların tam anlamıyla kabulünü savunan" bir kişi olarak tavsif eder. ${ }^{8}$ Dünyaca ünlü bir teolog ve ayrıca ruhban olan Hırvat kökenli Miroslav Volf ise hem Hirvatistan'daki Evanjelik hem de ABD'deki Episkopal Kilise'nin bir üyesidir. Miroslav Volf ile Yale Üniversitesi'nde görev yapan Pentakostal Kilisesi'nde bir ruhban olan Joseph Cumming Müslüman-Hıristiyan diyaloğu konusunda önemli faaliyetler yürütmektedirler. Ayrıca bu iki ismin çocukluklarından itibaren farklı din ve geleneklerin bir arada yaşandığı ortamlarda bulunduklarını belirtmek gerekir. ${ }^{9}$

"Yale Cevabı" kadar dikkat çekmemiş olsa da Dünya Baptist Birliğii'nin (Baptist World Alliance) cevabı AOK metniyle teolojik açıdan diyaloğa girmesi açısından önemlidir. Dünya Baptist Birliği de diğer Hıristiyan grupları gibi, her iki dinin öğretileri arasında farklılıklar olduğunun, her ikisindeki "Tanrı sevgisinin" ayrı olduğunun pek tabi ayırdındadır. Bunun yanı sıra her iki gelenekte de bu alanda örtüşen noktalar olduğunun farkındadır ve bu ortak noktaların karşı tarafa kendini açmada ve birlikte araştırmaya girişmekte "ortak bir zemin" ve "ortak söz" olacağını belirtmek suretiyle AOK'un çağrısına olumlu cevap verir (Coffey vd., 2012: 215). Dünya Baptist Birliği bu çağrıya sadece olumlu cevap vermekle ve ileride aktif projelerde yer almayı önermekle kalmaz, cevap metninde dahi AOK metninin ortaya koydukları ışı̆̆ında kendi Hıristiyan geleneğini yeniden okumaya girişir. Bunu yaparken de Müslüman muhataplarına sorular sorar. "Yale Cevabı"nda olduğu gibi

\footnotetext{
8 "Yale Cevabı"nın arkasındaki isimlerin dini aidiyetlerini öğrenmek için kendileriyle e-posta yoluyla iletişim kurdum ve kendilerini tanımlamaların istirham ettim. Yukarıdakiler e-postada bizzat onayladıkları, ifade ettikleri ya da başka yerde kaleme aldıkları bilgilerdir.

${ }^{9}$ Miroslav Volf için bk. https://www.fulcrum-anglican.org.uk/articles/miroslav-volf-faith-andreconciliation-a-personal-journey/ (01 Ekim 2016). Joseph Cumming için bk. http://www.josephcumming.com/Jesus/index.html (14 Ağustos 2016).
} 
bu cevapta da Hz. Muhammed'in defalarca "peygamber" sıfatıyla anılması dikkat çeker.

AOK yayımlandığından itibaren pek çok gelişme olmuş, bu çerçevede pek çok faaliyet düzenlenmiștir. Bunlardan başlıcaları Yale, Cambridge, Georgetown Üniversiteleri ile Dublin'deki Mater Dei Enstitüsü tarafindan düzenlenen ve AOK metni çerçevesinde şekillenen konferanslar ile Dünya Kiliseler Konseyi tarafından düzenlenen toplantılardır. Ayrıca, ilki 2008, sonuncusu 2014 tarihlerinde Roma'da üç Müslüman-Katolik Forumu düzenlenmiştir. ${ }^{10} \mathrm{AOK}$ 'a paralel ve onun üzerine bina edilen bir başka girişim de ilki Şubat 2011'de düzenlenen BM Dünya Dinlerarası Uyum Haftasıdır. Ürdün Kralı II. Abdullah 23 Eylül 2010' da New York'taki 65. BM genel kurul oturumunda Dünya Dinlerarası Uyum Haftası ile ilgili bir karar tasarısı sunmuş ve bu tasarı 20 Ekim 2010'da BM tarafından kabul edilmiştir. Böylece, her yılın Şubat ayının ilk haftası BM Dünya Dinlerarası Uyum Haftası ilan edilmiştir. ${ }^{11}$ Bu gelişmelerin yanı sıra AOK'u konu edinen pek çok kitap, makale ve lisansüstü tez kaleme alınmış, ${ }^{12} 1$ Ekim 2016 tarihi itibarıyla www.acommonword.com sitesi 500,000 'den fazla sayıda ziyaret almıştır. Ayrıca AOK Amerika Müslüman Sosyal Bilimciler'den 2008 Building Bridges ödülünü, Almanya'dan 2008 Eugen Biser ödülünü, İtalya'dan da Akdeniz'deki dinlerarası diyaloga katkı sağladığı için 2012 St. Augustine ödülünü almıştır.

\section{4. "Aramızdaki Ortak Kelime"yi Değerlendirme}

\section{1. Metnin Önemi}

AOK'u kısa zamanda dünya gündemine taşıyan en önemli özelliklerinden biri inisiyatif alan ve yetkili bir metin olmasıdır. Hatta onu Müslüman-Hıristiyan ilişkilerinde sadece son dönemlerde değil, yüzyıllardır Müslümanların inisiyatif başlattığı en önemli metin olarak da kabul etmek mümkündür. Metne cevap veren önemli isimlerden biri olan John Esposito bu girişimi "tarihte bir ilk" olarak niteler (Esposito, 2012: 139). AOK'un "Müslümanların Nostra Aetate'ye ilk ortak cevabı" (Madigan, 2012: 166) olarak görülebileceğini ifade eden Daniel Madigan'a göre bu metin "Vatikan mensupları tarafından dahi sıklıkla ifade edilen, Müslümanların teolojik diyaloğa girmede aciz" olduğu görüşünü yıkmaktadır (Madigan, 2012: 165). Ayrıca bu, Müslümanların görüş birliğinin büyük ölçüde sağlandığı önemli bir belgedir. Zira metin sadece Müslümanlarla Hıristiyanları değil Müslümanları kendi içinde de birleştirmiştir. Çünkü altında Sünni, Şii, İbadi, Zahiri vd. gibi pek çok farklı gelenekten Müslümanın imzası bulunur.

Üslup açısından bakıldığında, Papa'ya mektup polemikçi bir tarza sahipken AOK değildir. Zira Kitâb-1 Mukaddes'in tahrifi ya da tek bir Tanrı inancı ile alakalı tartı̧̧maya girmekten kaçınır. AOK İslamiyet ile Hıristiyanlık arasında farklılıkların olduğunu kabul etmekle birlikte, bu farklılıkları askıya alıp ortak noktalar üzerine

\footnotetext{
${ }^{10} \mathrm{AOK}$ çerçevesinde düzenlenen faaliyetlerle ilgili detaylı bilgi için bk. http://www.acommonword.com/category/new-fruits/major-a-common-word-events/ (15 Ekim 2016).

${ }^{11}$ Detaylı bilgi için bk. http://www.worldinterfaithharmonyweek.com (15 Ekim 2016).

${ }^{12}$ AOK ile ilgili yayınlar ve tezlerle ilgili detaylı bilgi için bk.

http://www.acommonword.com/category/new-fruits/publications/ (15 Ekim 2016).
} 
vurgu yapmak suretiyle diyaloğu önceler. Kitâb-1 Mukaddes'te çokça yer almasına rağmen Kur'an'da pek geçmeyen "sevgi" kavramı üzerinde durulması bu yaklaşıma bir örnektir. AOK'un "sevgi” kavramını vurgulamasının başkaca sebebini ise metnin yazılmasının geri zemin hikâyesinde bulabiliriz. Zira metnin yazarı Prens Gazi bin Muhammed'in de ifade ettiği gibi kendisi uzun zamandır bu konu üzerine kafa yormuş ve Cambridge Üniversitesi'nde 1988-1993 yılları arasında sevgi üzerine bir doktora tezi hazırlamıştır (Ghazi bin Muhammad, 2012: 131).

\section{2. Kutsal Kitaplardan Bölümlerin Kullanılması}

İki — ya da daha fazla — dini geleneğin kutsal metinlerini yan yana ele almak son dönemlerde Müslümanlar ve Hıristiyanlar arasındaki ortak faaliyetlerde sıklıkla kullanılan bir yöntem olarak karşımıza çıkar. Örneğin, Scriptural Reasoning ve Building Bridges Seminar bu faaliyetlerden ikisidir. AOK da Kitâb-1 Mukaddes ile Kur'an ayetlerini ve hadisleri yan yana sıralamak suretiyle İslam ve Hıristiyanlık arasında ortak olduğunu savunduğu Allah'ın birliği, Allah'1 ve kardeşi/komşuyu sevmeye vurgu yapar.

Yukarıda da bahsi geçtiği gibi AOK, Müslümanlarla Hıristiyanlar arasındaki ortak noktadan bahsederken Âl-i İmran Suresi'ndeki şu ayete vurgu yapar: "De ki: 'Ey kitap ehli! Bizimle sizin aranızdaki ortak bir kelimeye gelin: Yalnız Allah'a ibadet edelim. O'na hiçbir şeyi ortak koşmayalım. Allah'1 bırakıp da kimimiz kimimizi ilah edinmesin"” (Âl-i İmran, 64). Pek çok klasik âlim ve müfessir bu ayetin Hıristiyanlara reddiye olduğu görüşündedir. Zira pek çoğu bu ayetin tefsirinde Hz. İsa'ya Hiristiyanlar tarafından atfedilen ulûhiyet ve teslis inanciyla ilgili eleştiriler sıralamıştır. AOK'a cevap verenlerden Dünya Baptist Birliği bu ayetin klasik yorumlarının farkındadır. Zira burada ve metnin tamamında teslisi reddiye konusuna yer verilmemesini kendilerine karşı yapılmış bir "nezaket" olarak takdirle karşılayıp Müslümanlarla Hıristiyanlar arasındaki iletişimin bu şekilde ileri götürülebileceğini vurgular (Coffey vd., 2012: 224). Sonuçta, metin yazarları bu ayete yer vermiş olsa da Hıristiyanlığa reddiye tarzındaki klasik yorumlara yer vermemişlerdir. Kendisi de AOK'un etkin isimlerden biri olan Joseph Lumbard'a göre her ne kadar tarihte reddiyeci yaklaşım baskın olmuş olsa da bu yegâne değildir ve "Kur' an'ın çoğu ayetinde olduğu gibi bu ayeti anlamanın da pek çok yolu vardır." Lumbard bu görüşünü teyit amaciyla işârî müfessirlerden Alusi'nin (ö. 1854) ve Faslı Şazeli-Derkavi şeyhi İbn Acibe'nin (ö. 1809) mezkûr ayet yorumuna yer verir (Lumbard, 2012: 41, 50, dip. 56).

Ayrica AOK'un bazı ayetlere yer verip bazılarına yer vermemesi metinde kendini gösterir. Bu konuda en çarpıcı örnek İhlas Suresi'nin alıntılanması esnasında göze çarpar. İhlas Suresi'nin "De ki: 'O, Allah'tır, bir tektir.' 'Allah Samed'dir. (Her şey O'na muhtaçtır, O, hiçbir şeye muhtaç değildir)'” şeklindeki ilk kısmı alıntılandığı halde teslis öğretisinin eleştirisi olarak yorumlanan surenin devamı metinde yer almaz. Fakat bu durumun aksine, Fatiha Suresi'nin son ayeti klasik İslam müfessirleri tarafından Yahudi ve Hıristiyanlara eleştiri olarak yorumlanmasına rağmen $\mathrm{AOK}$ bu surenin tamamına yer verir. Bu üç örnek bizi şu sonuca götürür: AOK Hıristiyanlarla ortak noktaları ön plana çıkarmak gayesiyle polemik ortamı yaratabilecek ayet ve/veya ayet yorumlarını söz konusu etmekten kaçınır. 
İslami gelenekte yaygın olmayan Kitâb-1 Mukaddes ile Kur'an ayetlerinin yan yana anılması AOK'u imzalayan Müslümanların Hıristiyanların kutsal kitabını muharref olarak algılayıp algılamadığı sorusunu da gündeme getirmiştir. Bu konuda AOK sessizliğini korusa da Müslümanlardan muharref bir metinden alıntılar ile Kur'an ayetlerinin yan yana konulduğunu öne sürerek metne imza atmak istemeyenler olmuştur. Ayrıca, AOK İslami gelenekteki Kur'an ile Hıristiyanlık'taki Kitâb-1 Mukaddes'in statülerinin farklı olması üzerinde durmaz.

\section{3. Müslümanlar ve Hıristiyanlar Arasındaki Farklılıklar}

AOK'un Hıristiyanlar tarafından eksik görüldüğü önemli noktalardan biri iki din arasındaki farklı noktaların geri plana itilmesi ya da görmezden gelinmesidir. Pek çok Hıristiyan tek Tanrı'nın üçlü doğasının (yani teslisin) Hıristiyanlığın başlıca iman esası olduğunu ve bu durumda tek Tanrı'ya inanç etrafında buluşmanın çok da gerçekçi olmayacağını savunur. Örneğin, Christian Troll AOK'a verdiği cevapta Hıristiyan monoteizminin "teslisçi monoteizm" (trinitarian monotheism) olduğunu ve "Hıristiyanlar için İsa'nın hem tamamen insani hem de tamamen ilahi" olduğunu ifade eder. Troll'e göre AOK, İslamiyet'teki tevhit ile Hıristiyanlığın teslisçi monoteizmi arasındaki büyük farklılığı pek de önemser görünmez. Bu ise ona göre Müslüman-Hıristiyan diyaloğu önündeki önemli bir engeldir (Troll, Towards Common Ground between Christians and Muslims?) Canterbury Başepsikoposu Rowan Williams da cevabında - Troll'un yaklaşımından farklı da olsa - her iki inançtaki tek Tanrı anlayışının farklı olduğuna, Müslümanlar ve Hıristiyanların tek Tanrı'ya inansalar da Tanrı'nın doğası konusunda hemfikir olamayacaklarına dikkat çeker (Williams, 2012: 192-196). Bu eleștirilere karşı, AOK yazarı Prens Gazi’nin ifadesiyle, metinde "kasitlı olarak 'Huristiyanlık'taki teslis' konusunda bir bahis geçmez. Zira İsa (a.s.) İnciller'de böyle bir şeyden bahsetmez" (Ghazi bin Muhammad, 2010: 9).

Peki, her iki dindeki tek Tanrı inancında farklılıklar olduğuna göre, "Tanrı sevgisi” aynı mıdır? Madigan'a göre AOK'ta bahsi geçen, insanın Tanrı'ya olan sevgisi bir "zorunluluk" olduğu halde Hıristiyanlık'taki sevgi karşıllksızdır. Madigan Tanrı'nın karşılıksız sevgisini açıklamak için Yuhanna İncili ve Pavlus'un mektuplarına başvurur. Buna rağmen, Madigan'a göre - her ne kadar AOK metni söz konusu etmemiş olsa da - tasavvuftaki Allah aşkı Hıristiyanlık'taki sevgi anlayışına yakın düşmektedir. Bu da Müslümanlarla Hıristiyanlar arasında "devam eden teolojik diyalogda" önemli bir noktadır (Madigan, 2012: 170-171). Aynı şekilde Rowan Williams Tanrı sevgisiyle ilgili her iki gelenekteki benzeşen ve ayrışan noktalar 1şığında ileri çalışmalar yapılması gerektiğini ifade eder (Williams, 2012: 197). Dünya Baptist Birliği cevabında bunu bir adım daha ileri götürerek AOK metninde ortaya konulanlar ışı̆̆ında kendi Hıristiyan geleneğini okumaya girişir ve AOK'un da beklediği teolojik bir iletişime girer (Coffey vd., 2012: 219-221). Fakat aynı şekilde onlar da teslis konusunda Müslümanlardan farklı düşünüp inandıklarına dikkat çekerler (Coffey vd., 2012: 223).

\section{Sonuç Yerine}

Günümüzde birey, kurum ve grupların gerçekleştirdiği dinlerarası diyaloğun başlıca iki hedefi ve/veya metodu vardır: Birincisi diğer gelenekle iletişim halinde 
iken onu ve kendini tanıyıp konumlandırmak. Bu daha ziyade varoluşsal ve/veya bilişsel diyalogdur ve sınırlı bir kitleye mahsustur. İkincisi ise aşırıcılık, terör ve benzeri problemlere karşı çıkmak ya da ortak bir yapılandırıcı proje gerçekleştirmek gibi pratik bir amaç için birlikte hareket etmektir. Yukarıdaki değerlendirmelerin 1şı̆̆ında "Aramızdaki Ortak Kelime" girişimini ele alacak olursak, metnin içeriğinden ziyade ortaya konuluş amacını ve uyandırdığı yankıyı göz önünde bulundurmak faydalı olur. AOK'u amaç, metot ve içerik bakımından ele alacak olursak, yukarıdaki şıklardan ikisini de kapsadığını görürüz. Zira bu hem teolojik hem de teolojik olmayan bir girişimdir. Öncelikle metnin yazarlarının da ifade ettiği gibi teolojiktir çünkü Kur'an, hadisler ve Kitâb-1 Mukaddes'i yan yana okumak ve ortak noktalara işaret etmek suretiyle teolojik bir diyalog önerir. Bunun yanı sıra, Tim Winter'ın da belirttiği gibi, AOK siyasi birlik amaciyla ortaya konmuş bir metindir. Ayrıca güncel akademik ve teolojik bir derinliğe sahip olmadığı gibi çoğunlukla entelektüel seviyede kalmış, halk seviyesine pek de in(e)memiştir. Görünen o ki, AOK metot olarak teolojik olsa da gayesi itibarıyla pratik bir metindir. Belki de AOK'u amacı, metodu, siyakı ve sibakıyla ele aldığımızda "teopolitik" olarak adlandırmak en uygunu olacaktır.

Metni uyandırdığı yankı ya da sonuç açısından ele alacak olursak, Joseph Lumbard'ın belirttiği gibi AOK'un vesile olduğu Yale Konferansı'nda Müslüman dünyanın önde gelen vaizlerinden Habib Ali el-Cifri ile Hıristiyan televizyon vaizi Robert Schuller aynı sahnede yer almış (Lumbard, 2012: 26), konferansa katılanlar "dünyadaki yoksulluğa, Irak ve Afganistan'daki savaşlara, Filistin ile İsrail'deki duruma, gelecekteki olası savaşlara ve dini özgürlük” gibi konulara değinmişlerdir (Yale University Workshop and Conference on A Common Word: Final Statement from Yale). Aynı şekilde Cambridge Üniversitesi'nde Rowan Williams'ın girişimiyle gerçekleştirilen konferansa Müslüman dünyanın önde gelen isimlerinden Abdullah bin Beyye, Ramazan el-Buti ve Şeyh Ali Cuma gibi isimler katılmış, dünyadaki önemli sorunlara dikkat çekmişlerdir. AOK Vatikan'ın Müslümanlarla diyaloğunda da önemli bir dönüm noktası olmuştur.

Aslında, Vatikan'ın AOK karşısında takındığı tavrı 1965 yılından itibaren Katolik dünyada önem kazanan Müslüman-Hıristiyan ilişkileri çerçevesinde ele almak gerekir. Vatikan 1965 yllından itibaren - her ne kadar kurtuluşun ancak Mesih vasıtasıyla gerçekleşebileceğini savunmaya devam etse de - Müslümanların inançlarındaki güzelliklere dikkat çeker. ${ }^{13}$ Nostra Aetate' nin akabinde Papa II. John Paul her ne kadar Müslümanlar hakkında olumlu bir yaklaşım sergilemiş olsa da bu durum (Regensburg konuşması örneğinde olduğu gibi) Papa XVI. Benedikt zamanında olumsuz bir tona bürünmüștür. Yukarıda da sözü geçtiği gibi Vatikan AOK'a gecikmeli bir tepki göstermiş, fakat ilerleyen günlerde Papa XVI. Benedikt AOK çerçevesinde Kasım 2008'de gerçekleştirilen I. Katolik-Müslüman Forumu'nda aşağıdaki sözlerin geçtiği bir konuşma yapmıştır:

Pek tabii farkındayım ki, Müslümanlarla Hıristiyanlar Tanrı ile ilgili mevzularda farklı yaklaşımlara sahipler. Buna rağmen bizi yaratan ve dünyanın her köşesindeki her bir insanla ilgilenen tek Tanrı'ya kulluk edebiliriz ve etmeliyiz. Karşılıklı saygı

${ }^{13}$ Örneğin bk. Nostra Aetate, kısım 2-3,

http://www.vatican.va/archive/hist_councils/ii_vatican_council/documents/vatii_decl_19651028_nostra-aetate_en.html (25 Eylül 2016). 
ve dayanışmamızla beraberce göstermeliyiz ki, kendimizi tek bir ailenin üyeleri addediyoruz; Tanrı'nın sevdiği ve dünyanın yaratılışından insanlık tarihinin sonuna kadar bir araya topladığ 1 bir aile.

Yukarıdaki sözlerin yanı sıra Papa'nın aynı konuşmada insanlığın iyiliği için ortaklaşa çalışılması gerektiğini vurgulaması, AOK'un maksadının belli ölçüde hâsıl olduğunu ve Papa'nın Regensburg konuşmasındaki olumsuz yaklaşımdan geri adım attığını gösterir.

Günümüzde Müslümanlar tarafindan dinlerarası diyaloğa karşı çıkılmasındaki başlıca sebeplerinden biri İslamiyet ve Hıristiyanlık arasındaki teolojik farkl1l1kların yok edilip her iki dinin ortak bir noktada birleştirileceği endişesidir. Bunun sonucunda da diyalog bir Truva atı olarak algılanır. Fakat görüldüğü gibi AOK aslında İslamiyet ve Hıristiyanlık arasındaki teolojik farklı1ıkların pek tabii farkındadır. Dahası bu farklılıkları ne aza indirmek ne de göz ardı etmek niyetinde değildir. Bilakis bu teolojik farklılıkların varlığının ortak bir dini dil etrafında ve modern seküler hümanizme karşı birleşmeye engel olmaması dileğindedir. Tam da bu noktada Gelenekselci okul ve religio perennis (perenniyal din) yaklaşımının AOK üzerinde etkili olup olmadığı sorusu ortaya çıkar. Zira her ne kadar geçen yüzyılda René Guénon (ö. 1951) ve Frithjof Schuon (ö. 1998) tarafından başı çekilen Gelenekselci bir metafiziğin metinde bire bir etkili olması tartış1lır olsa da bu okulun üzerinde önemle durduğu konulardan biri olan modern sekülerleşmeye karşı yaptığı maneviyat vurgusu gözlerden kaçmaz. Metin İslami veçheden her ne kadar Kur'an ayetleri üzerinden şekillense de yazarlarının entelektüel ve manevi anlamda tasavvuf ve İslam felsefesinden ilham almaları dikkat çeker. Ayrıca, metni imzalayanalar arasında tarikat ehlinin, özellikle de Şazeli tarikatının, onun da Meryemiyye kolunun, etkin varlığından söz etmek yerinde olur. Buna ilaveten metni imzalayanların en önemli özelliklerinden biri dini inançlarına gerçekten bağlı Müslümanlar olmalarıdır. Ayrıca bir hadis ile Kitâb-1 Mukaddes'teki bir emri çok benzer bulan metin, Hz. Muhammed'in sözü geçen kısmı "ilham vasıtasıyla tekrarlıyor ve ona gönderme yapıyor" olabileceğini iddia etmek suretiyle ortak bir nebevi hikmete vurgu yapar (The 'A Common Word' Text, 2012: 65). Bu tarz bir yaklaşım genel olarak Kur'an'dan mülhem bir tarih teolojisine denk düşse de özel olarak pek tabii Gelenekselci okulun ortak evrensel bir payda vurgusu olarak görülebilir.

Metinde görülür ki, bir kısmı Gelenekselci okula mensup ve pek çoğu tasavvuf ehli olan AOK yazarları muhtemelen kendi İslami yaklaşımlarını Kur'an'dan seçtikleri bazı ayetler vasıtasıyla duyurmak istemişlerdir. Sevgi konusunda çıkış noktaları Hıristiyan geleneği olduğu için biraz zorlamayla bunun Kur'an'dan ayetlerle paralelini bulmaya çalışmak yerine bu konuda kaynak olarak gösterilen bazı kutsi hadislere yer vermeleri ve sevginin tasavvuf geleneğindeki şekline vurgu yapmaları daha verimli olabilirdi. Zira nasıl İslamiyet'teki tevhidin paraleli Hıristiyan geleneğinde arandığında teslisçi monoteizm ortaya çıkıyorsa AOK'un tasvir ettiği gibi kişinin kendini tamamen Allah'a adaması ve O'na kulluk etmesi Hıristiyanlık'taki Tanrı sevgisi anlayışıyla aynı değildir. Örneğin, Hıristiyan geleneği Mesih'ten önce Musa'ya verilen Yasa'nın Hıristiyanlık'taki Tanrı sevgisi ile karşılaştırıldığında daha aşağı seviyede olduğunu ifade eder. Zira genel Hiristiyan anlayışına göre Yasa korku barındırmakta iken, Baba koşulsuz sevgisiyle Oğlu Mesih'i insanlığı kurtarma gayesiyle feda etmiştir. Bu durumda Hıristiyanlık'taki 
Tanrı'nın insanlık için kendi tek Oğlu'nu feda etmesinin İslami gelenekte tam karşılığ karşılığ 1 ancak Yasa ve zorunluluk, sonuç olarak da Hıristiyanlık tarafından bir "küçümsenme" olacaktır. Bu sebeple kutsal metinlerin paralel şekilde yan yana konulup onların gelenek içinde uygulama ve yorumlanma şeklini göz ardı etmek suni ortak nokta arayışı anlamına gelir. Bu durum ise teolojik, evrensel ve bir nevi suni paydalar üzerinde durmanın faydadan ziyade açmazlara sebep olacağı gerçeğini gözler önüne serer. Ayrıca, AOK Hıristiyan tarafından İslami tevhitçi bir tebliğ ya da tevhit anlayışını Hıristiyan geleneğinin üstüne giydirme gayreti olarak yorumlanabileceği gibi, Müslüman tarafından da Hıristiyanlık'taki Tanrı sevgisi anlayışının İslami geleneğin üstüne giydirilme çabası olarak yorumlanabilir.

Bununla beraber, görüldüğü gibi, her ne kadar Tanrı'nın birliği ve sevgisi İslamiyet ve Hıristiyanlık arasında tamamen örtüşen ortak paydalar sayılamasa da kardeş/komşu sevgisi ile günümüzde adalete duyulan ihtiyaç pek tabii evrensel ortak paydalar olarak görülebilir. O halde, Müslümanlarla Hıristiyanların birbirleriyle iyi ilişkiler kurup komşuca yaşamaya çalışmaları diyalog için daha verimli bir yaklaşım olacaktır. Ayrıca, kanaatimce, çıkış noktası olarak da Asr Suresi'nde geçen "Andolsun zamana ki, insan gerçekten ziyan içindedir. Ancak, iman edip de salih ameller işleyenler, birbirlerine hakkı tavsiye edenler, birbirlerine sabrı tavsiye edenler başka" ayetlerinin ön plana çıkarılması AOK'un sebep olduğu teolojik tartışmaları ve örtüşmezlikleri asgariye indirebilirdi. Son kertede AOK metin olarak içerisinde zayıflıklar ve problemler barındırmakla birlikte onu sadece metin olarak değil bağlamı ve etkisi itibarıyla değerlendirmek, "medeniyetler çatışması" tezine bir cevap olarak Müslümanların Hıristiyan komşularıyla bir ittifak kurma gayreti ve Hıristiyan dünyaya uzatılmış eli olarak görmek gerekir. Bu veçheden baktığımızda AOK çerçevesinde farklı düşünce ve mezheplerden Müslümanlar uzun zamandır ilk kez birleşmiş ve yüzyıllardır erteledikleri inisiyatif sahibi bir konumda Hıristiyan dünyaya çağrıda bulunmuşlardır. $\mathrm{Bu}$ sonuçlar, kanaatimce, $\mathrm{AOK}$ metninin problemlerine takılıp da heba edilmeyecek kadar önemli ve değerlidir.

Sonuç olarak, günümüz Türkiyesi'nde hâlâ dinlerarası diyaloğun yapılıp yapılamayacağı tartışıladursun beynelmilel alanda böyle faaliyetler hâlihazırda sürdürülüyor. Örneğin, İslam karşıtlığının had safhada oluğu günümüz Amerika'sında Pakistan kökenli bir Müslüman, beyaz Amerikalı ve Katolik komşusuyla ister istemez dini temaların ön plana çıktığı bir münasebet kuracaktır. Ya da Lübnan'daki Maruni bir Hıristiyan Sünni ve Şii Müslümanlarla bir araya gelip ortak “düşmanları" komşu İsrail' in gölgesinde dini kimliklerinin ön plana çıktığı bir iş birliği platformu kuracaklardır. Çok sınırlı sayıda ve ölçekte de olsa Katolik, akademisyen bir Alman kendi kutsal metnini Müslümanların da olduğu bir toplulukta Kur'an ile yan yana okumak ya da kendi teolojisini İslami teolojiyle mukayese halinde anlamak ve yorumlamak isteyebilecektir. Bu durumda özellikle milliyetçi reflekslerin hâkim olduğu hamasi bir tartışmaya girmek yerine dünyada sürdürülegelen diyalog faaliyet ve hareketlerini incelemek, onların iç dinamiklerini, dış bağlamlarını irdelemek suretiyle bu faaliyet ve yaklaşımlar hakkında elle tutulur ve şahsına münhasır bilgi edinmek ve bunun küçük ölçekte Türkiye gerçeğine uyup uymayacağını tartışmak daha faydalı olacaktır. Buna ilaveten, sadra şifa olması istenen dinlerarası bir diyaloğun öncesinde din içi diyalog öngörülmelidir. Zira din içi diyaloğu önemsemeyen bir kimse ya da kurumun dinlerarası diyalogda ne derece 
samimi olabileceği tartışılır. Örneğin, Roman vatandaşların toplumla bütünleşmesini ya da Alevi-Sünni diyaloğunu önemsemeyen bir Türkiye'nin Katolik dünya ile iletişim kurmaya çalışmasının nedenlerini sorgulamak gerekir. Ayrıca, dinlerarası diyalog faaliyet ve yaklaşımlarının fayda sağlamayacağı düşünülürse bunları hamasi bir yaklaşımla eleştirmek, hakarete varan dışlayıcı bir tutum sergilemek yerine birey ya da topluma düşen, iletişim için kendi özgün çaresini yaratmak olacaktır. Zira dünyadaki diyalog çalışmaları bir ya da birçok amaca matuf doğmuş ve hizmet vermektedir. Unutulmamalıdır ki, Türkiye dünyanın bütününden küçüktür.

\section{Kaynaklar}

MABDA. (2012). The 'A Common Word' Text. A Common Word Between Us and You: 5-Year Anniversary Edition içinde (s. 51-79). Amman: The Royal Aal Al-Bayt Institute for Islamic Thought.

Bardakoğlu, A. (2006). Papa Özür Dilemeli. http://arsiv.ntv.com.tr/news/384999.asp (15 Ekim 2016).

Bush, G.W. (2001). Remarks by the President Upon Arrival. https://georgewbushwhitehouse.archives.gov/news/releases/2001/09/20010916-2.html (6 Ağustos 2016).

Coffey, D. vd. (2012). Extended Response from the Baptist World Alliance.

MABDA, A Common Word Between Us and You: 5-Year Anniversary Edition içinde (s. 213-234). Amman: The Royal Aal Al-Bayt Institute for Islamic Thought.

Esposito, J. (2012). AOK'a Cevap. MABDA, A Common Word Between Us and You: 5-Year Anniversary Edition içinde (s. 139). Amman: The Royal Aal Al-Bayt Institute for Islamic Thought.

Ghazi bin Muhammad. (2012). The Genesis of 'A Common Word.' MABDA, $A$ Common Word Between Us and You: 5-Year Anniversary Edition içinde (s. 131-134). Amman: The Royal Aal Al-Bayt Institute for Islamic Thought.

Ghazi bin Muhammad. (2010). On 'A Common Word Between Us and You.' M. Volf vd. (Eds.), A Common Word: Muslims and Christians on Loving God and Neighbor içinde (s. 3-17). Grand Rapids, Mich.: W.B. Eerdmans Pub. Co.

Ghazi bin Muhammad ve Nayed, A.A. (2010). Frequently Asked Questions That Muslims Have Been Asked about 'A Common Word.' M. Volf vd. (Eds.), A Common Word: Muslims and Christians on Loving God and Neighbor içinde (s. 171-177). Grand Rapids, Mich.: W.B. Eerdmans Pub. Co.

Loving God and Neighbor Together: A Christian Response to A Common Word 
Yalova Sosyal Bilimler Dergisi

Between Us and You. (Kasim 2007). http://faith.yale.edu/commonword/common-word-christian-response (15 Ekim 2016).

Lumbard, J. (2012). The Uncommonality of 'A Common Word.' MABDA, A Common Word Between Us and You: 5-Year Anniversary Edition içinde (s. 11-50). Amman: The Royal Aal Al-Bayt Institute for Islamic Thought.

Madigan, D. (2012). A Common Word Between Us and You: Some Initial Reflections. MABDA, A Common Word Between Us and You: 5-Year Anniversary Edition içinde (s. 165-175). Amman: The Royal Aal Al-Bayt Institute for Islamic Thought.

Nayed, A. A. (2006). A Muslim's Commentary on Benedict XVI's 'Faith, Reason and the University: Memories and Reflections.' http://www.masud.co.uk/ISLAM/misc/commentary_on_benedict.php (15 Ekim 2016).

Öktem, E. (2002). Fethullah Gülen Hareketi ve Dinlerarası Diyalog. C. Uşak (Ed.), Küresel Barışa Doğru: Kozadan Kelebeğe 3 içinde (s. 131-141). İstanbul: Gazeteciler ve Yazarlar Vakfi.

Papa XVI. Benedikt Cenapları'na Açık Mektup. (Ekim 2006). http://www.gluefox.com/orel/openletter-8238DA.pdf (15 Ekim 2016).

Papa XVI. Benedikt. (2006). İman, Akıl ve Üniversite: Hatıralar, Değerlendirmeler. http://w2.vatican.va/content/benedictxvi/en/speeches/2006/september/documents/hf_benxvi_spe_20060912_university-regensburg.html (15 Ekim 2016).

Papa XVI. Benedikt. (Kasım 2008). I. Katolik Müslüman Forumu konuşmas1. http://www.acommonword.com/the-popes-speech/ (15 Ekim 2016).

Troll, C. (t.y.). Towards Common Ground between Christians and Muslims? 138 Muslim Religious Leaders Call for Reconciliation and Cooperation with Christians. http://www.acommonword.com/response-from-prof-drchristian-troll-s-j/ (15 Ekim 2016).

Williams, R. (2012). A Common Word for the Common Good. MABDA, A Common Word Between Us and You: 5-Year Anniversary Edition içinde (s. 187-212). Amman: The Royal Aal Al-Bayt Institute for Islamic Thought.

Winter, T. (Aralık 2013). Mater Dei Institute of Education'da gerçekleştirilen 'A Common Word' and the Future of Muslim-Christian Dialogue Konferans1 açış konuşması, Dublin.

Yale University Workshop and Conference on A Common Word: Final Statement from Yale. (t.y.). http://www.acommonword.com/category/newfruits/major-a-common-word-events/ (15 Ekim 2016). 